\title{
A cause of erroneous diagnosis of pigmented villonodular synovitis
}

\author{
R. A. BURNETT \\ From the University of Glasgow, Department of Pathology, Western Infirmary, Glasgow G11 6 NT
}

SYNOPSIS An unusual type of benign vascular hamartoma, which shows a curious papillary organization of thrombus and abundant haemosiderin deposition, is liable to be misdiagnosed histologically as pigmented villonodular synovitis. Nine examples of this type of lesion are briefly presented and the differential diagnosis is discussed.

Pigmented villonodular synovitis (PVNS) is an uncommon synovial lesion of uncertain nature which is locally invasive and shows a propensity for recurrence after surgical excision. It may involve articular, bursal or tendon sheath synovium either diffusely or in a nodular form. The finger and hand are by far the commonest areas to be affected (Wright, 1949) and at these sites the lesion is almost invariably of the nodular type (Byers et al, 1968). PVNS must be distinguished from synovial sarcoma, other tumours containing giant cells, osteochondromatosis, and granulomatous inflammatory reactions involving the synovium. Reported here are nine cases of an uncommon type of vascular hamartoma, seven of which were mistaken histologically for PVNS. These lesions show an unusual papillary organization of thrombus with much haemosiderin deposition. This type of organization has been described only once before in the literature (Sevitt, 1973) and this source of diagnostic error has not previously been reported.

\section{Material and Methods}

Of the nine cases presented here, seven were erroneously diagnosed as PVNS. Three of these cases (3, 5 , and 9) were referred for histological opinion from other hospitals in the Glasgow area. The other four cases $(1,2,7$, and 8$)$ were recognized during a review of all the reported examples of PVNS in the departmental files of this hospital over the last 23 years (table I). All four lesions occurred in either the finger or the hand and represent a significant proportion of the total digital and hand PVNS lesions reviewed over this period (69 cases). The other two cases (4 and 6), although originally diagnosed as

Received for publication 10 July 1975.

\begin{tabular}{|c|c|c|c|}
\hline \multirow[t]{2}{*}{ Site } & \multicolumn{3}{|c|}{ Number of Cases (Sex ratio M:F) } \\
\hline & Diffuse & Nodular & Total \\
\hline Finger and hand & - & $\begin{array}{l}69 \\
(23: 46)\end{array}$ & 69 \\
\hline Knee & $\begin{array}{l}5 \\
(3: 2)\end{array}$ & $\begin{array}{c}7 \\
(2: 5)\end{array}$ & 12 \\
\hline Ankle & $\begin{array}{l}1 \\
\text { (M) }\end{array}$ & $\begin{array}{c}3 \\
(2: 1)\end{array}$ & 4 \\
\hline Foot & - & $\begin{array}{l}2 \\
(1: 1)\end{array}$ & 2 \\
\hline Wrist & - & $\begin{array}{l}1 \\
(\mathrm{~F})\end{array}$ & 1 \\
\hline Hip & - & 1 & 1 \\
\hline Total & 6 & 83 & 89 \\
\hline
\end{tabular}

Table I PVNS-Western Infirmary, Glasgow 1952-74

vascular hamartomata, are included here because they show identical clinical and histological features. All these specimens were examined using standard histological tissue processing and staining techniques.

\section{Clinical Features}

The clinical features are shown in table II. In seven patients the lesion occlurred in the finger or hand, but an identical histological picture was also seen in the tissue obtained from a lesion within the triceps muscle of a 14-year-old boy (case 3) and from a second excision of a lesion in the calf muscles of a 4-year-old girl (case 5). Although the second specimen from case 5 was misinterpreted as pigmented villonodular synovitis, the original excision had shown a simple vascular hamartoma which consisted of large blood-filled spaces but contained no thrombus and hence no papillary pattern liable to be confused with PVNS. 


\begin{tabular}{|c|c|c|c|c|c|c|c|c|}
\hline Case & Sex & Age & Site of Lesion & $\begin{array}{l}\text { Duration of } \\
\text { Symptoms }\end{array}$ & $\begin{array}{l}\text { Max. Diameter } \\
\text { of Lesion }\end{array}$ & Pain & $\begin{array}{l}\text { Original } \\
\text { Diagnosis } \\
\text { (Histological) }\end{array}$ & Comment \\
\hline 1 & $\mathbf{F}$ & 35 & $\begin{array}{l}\text { L. second finger middle } \\
\text { phalanx, palmar aspect. } \\
\text { Recurrence after } 18 \text { months }\end{array}$ & 1 month & $\begin{array}{l}10 \mathrm{~mm} \\
20 \mathrm{~mm}\end{array}$ & $\begin{array}{l}\text { Slight } \\
\text { Slight }\end{array}$ & $\begin{array}{l}\text { PVNS } \\
\text { PVNS }\end{array}$ & $\begin{array}{l}\text { Cystic lesion in subcutaneous } \\
\text { tissue, no attachment to } \\
\text { tendons. Re-excision after } \\
18 \text { months. Since then no } \\
\text { recurrence after } 20 \text { years }\end{array}$ \\
\hline 2 & $\mathbf{M}$ & 26 & $\begin{array}{l}\text { L. fourth finger, middle } \\
\text { phalanx palmar aspect }\end{array}$ & 1 month & $10 \mathrm{~mm}$ & $\begin{array}{l}\text { Slight on } \\
\text { movement }\end{array}$ & PVNS & $\begin{array}{l}\text { Soft, dark, cystic, vascular } \\
\text { tumour }\end{array}$ \\
\hline 3 & $\mathbf{M}$ & 14 & $\begin{array}{l}\text { Within triceps muscle } \\
\text { above elbow joint }\end{array}$ & 6 months & Small & Intermittent & PVNS & No follow-up available \\
\hline 4 & $\mathrm{~F}$ & 21 & $\begin{array}{l}\text { R. second and third } \\
\text { fingers web palmar } \\
\text { aspect }\end{array}$ & 12 months & $10 \mathrm{~mm}$ & $\begin{array}{l}\text { Recently } \\
\text { became swollen } \\
\text { and painful }\end{array}$ & VH & $\begin{array}{l}\text { Superficial, not attached to } \\
\text { tendons. No recurrence after } \\
1 \text { year }\end{array}$ \\
\hline 5 & $\mathbf{F}$ & 4 & $\begin{array}{l}\text { Within gastrocnemius } \\
\text { muscle }\end{array}$ & $\begin{array}{l}\text { History of } \\
\text { minor trauma } \\
4 \text { months } \\
\text { previously }\end{array}$ & $20 \mathrm{~mm}$ & None & VH & $\begin{array}{l}\text { Primary excision incomplete. } \\
\text { Fibrous capsule }\end{array}$ \\
\hline & & & Recurrence after 18 months & - & $20 \mathrm{~mm}$ & None & PVNS & \\
\hline 6 & $\mathbf{F}$ & 62 & $\begin{array}{l}\text { L. third finger, terminal } \\
\text { phalanx, lateral aspect }\end{array}$ & 3 months & $15 \mathrm{~mm}$ & None & VH & $\begin{array}{l}\text { Subcutaneous, haemorrhagic } \\
\text { lesion }\end{array}$ \\
\hline 7 & $\mathbf{M}$ & 43 & R. hand, palmar aspect & $\begin{array}{l}\text { History of } \\
\text { trauma } 6 \text { montl } \\
\text { previously }\end{array}$ & $\begin{array}{l}30 \mathrm{~mm} \\
\text { ths }\end{array}$ & Tender & PVNS & $\begin{array}{l}\text { Superficial to flexor sheath, } \\
\text { no recurrence after } 2 \text { years }\end{array}$ \\
\hline 8 & $\mathbf{M}$ & 29 & $\begin{array}{l}\text { R. thumb, distal phalanx } \\
\text { radial aspect }\end{array}$ & 12 months & $15 \mathrm{~mm}$ & $\begin{array}{l}\text { Only on } \\
\text { gripping }\end{array}$ & PVNS & Clinically 'mucous cyst' \\
\hline 9 & $\mathbf{F}$ & 67 & Index finger & $\begin{array}{l}3 \text { months } \\
\text { following a } \\
\text { burn }\end{array}$ & $10 \mathrm{~mm}$ & 一 & PVNS & - \\
\hline
\end{tabular}

Table II Clinical features

$\mathbf{V H}=$ vascular hamartoma

\section{Pathology}

These vascular hamartomata were all between 10 and $30 \mathrm{~mm}$ in their largest diameter and tended to be nodular. They often appeared cystic or haemorrhagic and had well-defined margins. Histologically they consisted of rather large, but irregularly shaped, vascular spaces. The walls of most of these spaces were rather thickened and many contained a welldefined layer of smooth muscle, often sited immediately beneath the endothelium. Variable but usually scanty amounts of elastic tissue were also seen. The growth of fibroblasts and capillary blood vessels into the thrombus, which was present in many of these spaces, produced a papillary pattern, and adjacent granulation tissue contained numerous, poorly formed, slitlike, vascular channels (fig 1). Large amounts of haemosiderin were invariably present. The appearances of the thrombus in all these cases are identical with the 'organic fragmentation' type of organization of thrombus, originally described by Sevitt (1973) in his account of canalization in venous thrombosis.

\section{Discussion}

The features that led to the confusion between these vascular hamartomata and PVNS are threefold:
(1) The papillary pattern produced by the organization of the more superficial part of the thrombus may simulate synovial villi (fig 2 ). However, these projections are often more delicate and do not usually contain blood vessels. The smaller ones consist of pale-staining, almost acellular collagen.

(2) The more solid parts of the granulation tissue which has replaced thrombus may contain many thin-walled, slitlike, vascular channels, and these may be mistaken for synovial clefts caused by the matting together of synovial villi (fig 3). The cells lining these spaces, however, are spindle-shaped and do not contain iron. The channels are smaller and more orderly in arrangement than the irregular, coarse, sponge-like pattern of villous matting.

(3) The lumina of the vascular channels composing the hamartoma may also be misinterpreted as synovial surfaces, but there is often an incomplete layer of smooth muscle immediately beneath the lining cells, a feature which is not present in synovium. In spite of the vascularity of the synovium in PVNS, the presence of organizing thrombus on the synovial surface is distinctly uncommon.

Although abundant haemosiderin is present in these lesions (fig 4), no giant cells or sheets of xanthoma cells are seen. Except for the haemosiderincontaining macrophages, there is a lack of the 


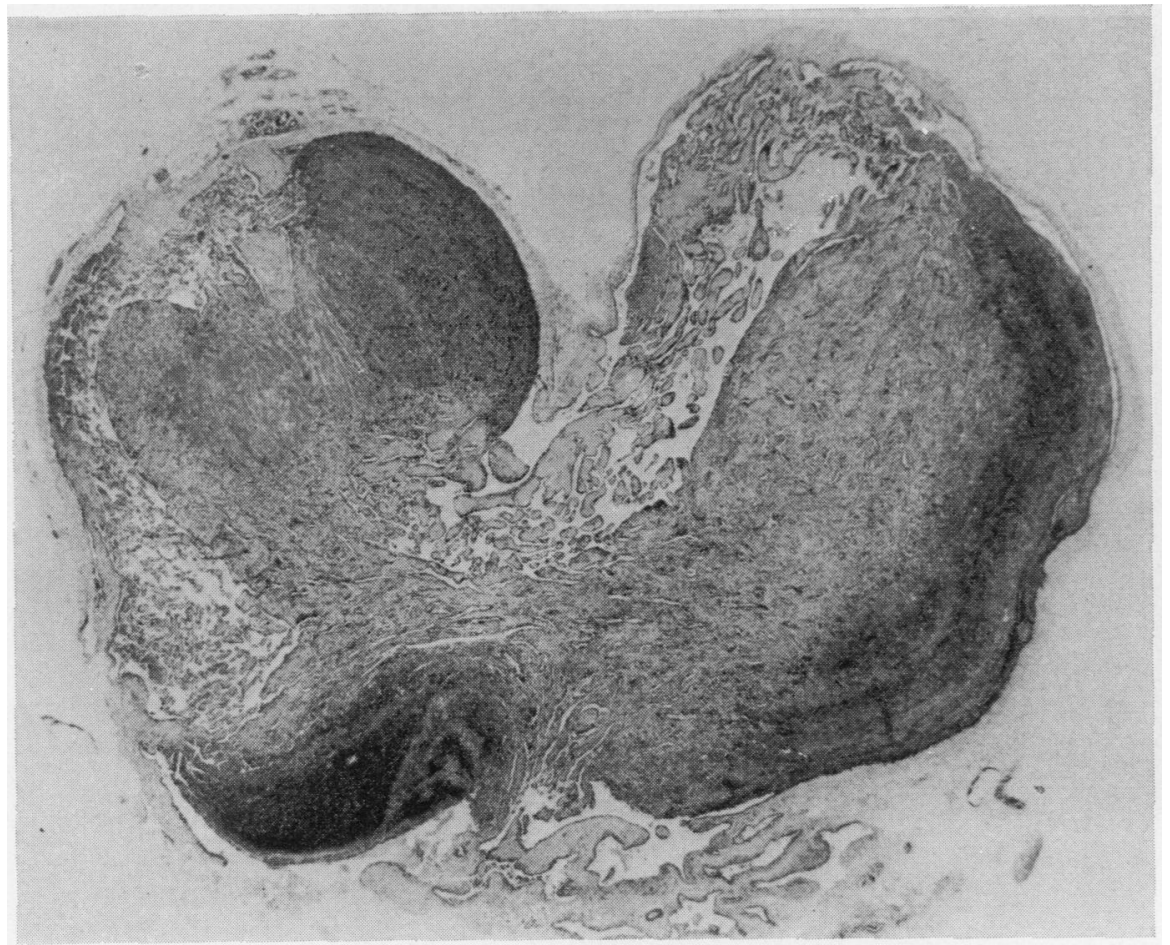

Fig 1 Low-power view of part of the lesion in case 4. $A$ distended vascular space containing organizing thrombus is shown. In several areas a pronounced papillary pattern is evident, and more solid regions contain numerous slitlike channels. Several collapsed, vascular spaces in direct continuity with the thrombosed vessel are present at the bottom of the picture.

Haematoxylin and $\operatorname{eosin} \times 20$.

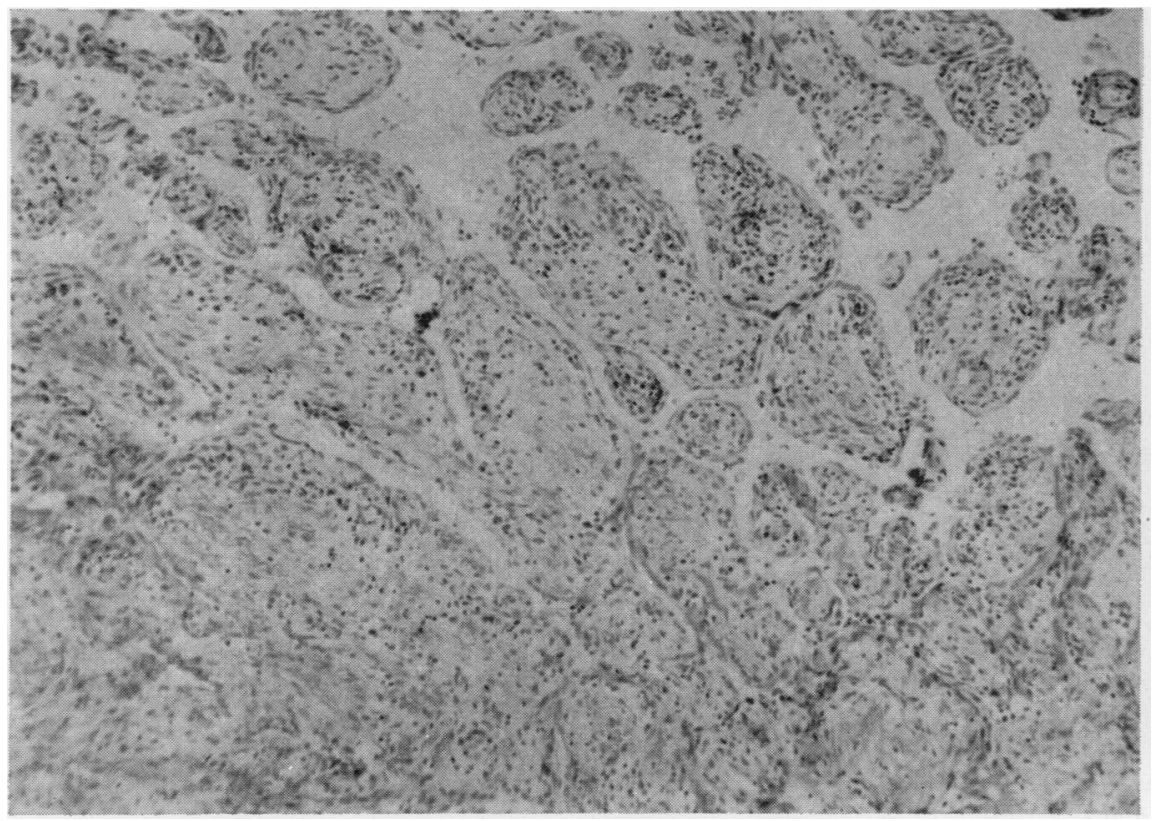

Fig 2 Case 8. The superficial portion of the organizing thrombus has produced a papillary pattern which simulates synovial villi. Most of the projections are avascular. Quantities of iron are present. $H$ and $E \times 75$ 


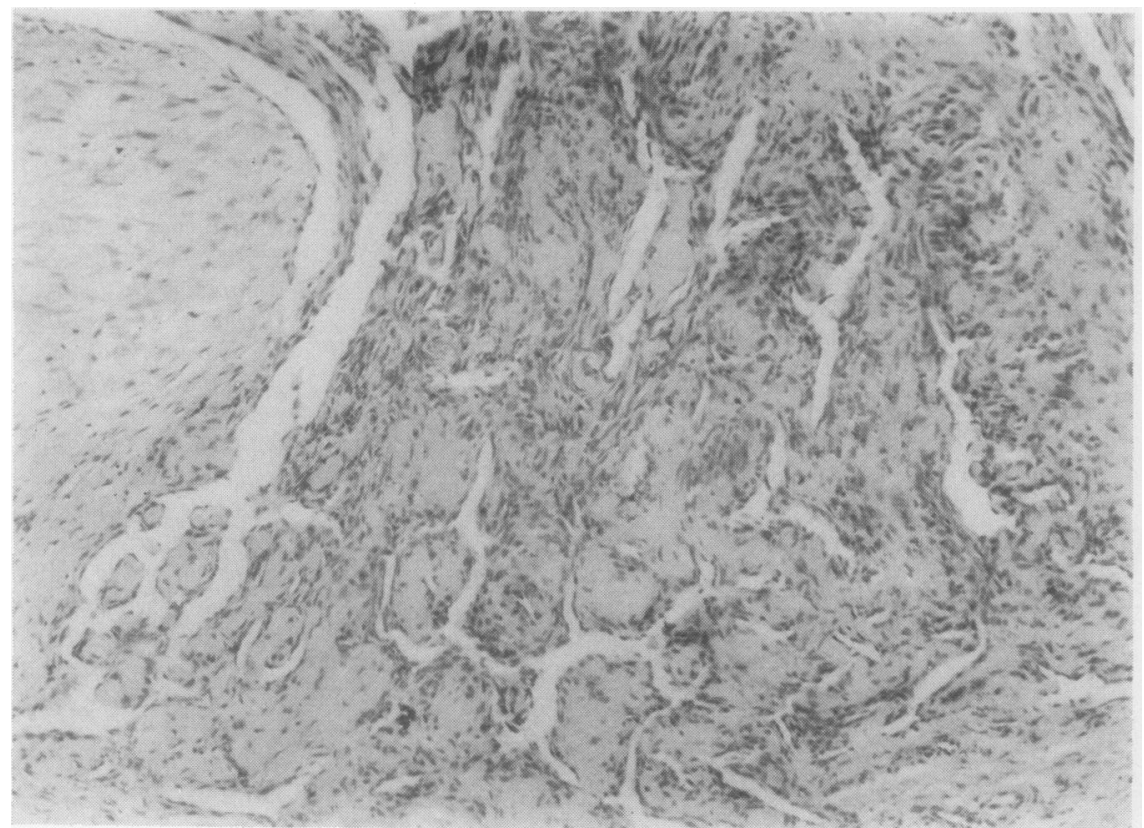

Fig 3 Case 6.

Numerous slitlike vascular channels are present in this area of organizing thrombus. This appearance may be mistaken for villous matting. The wall of the vascular channel, cut rather obliquely, is seen at the top left of the picture. $H$ and $E \times 75$

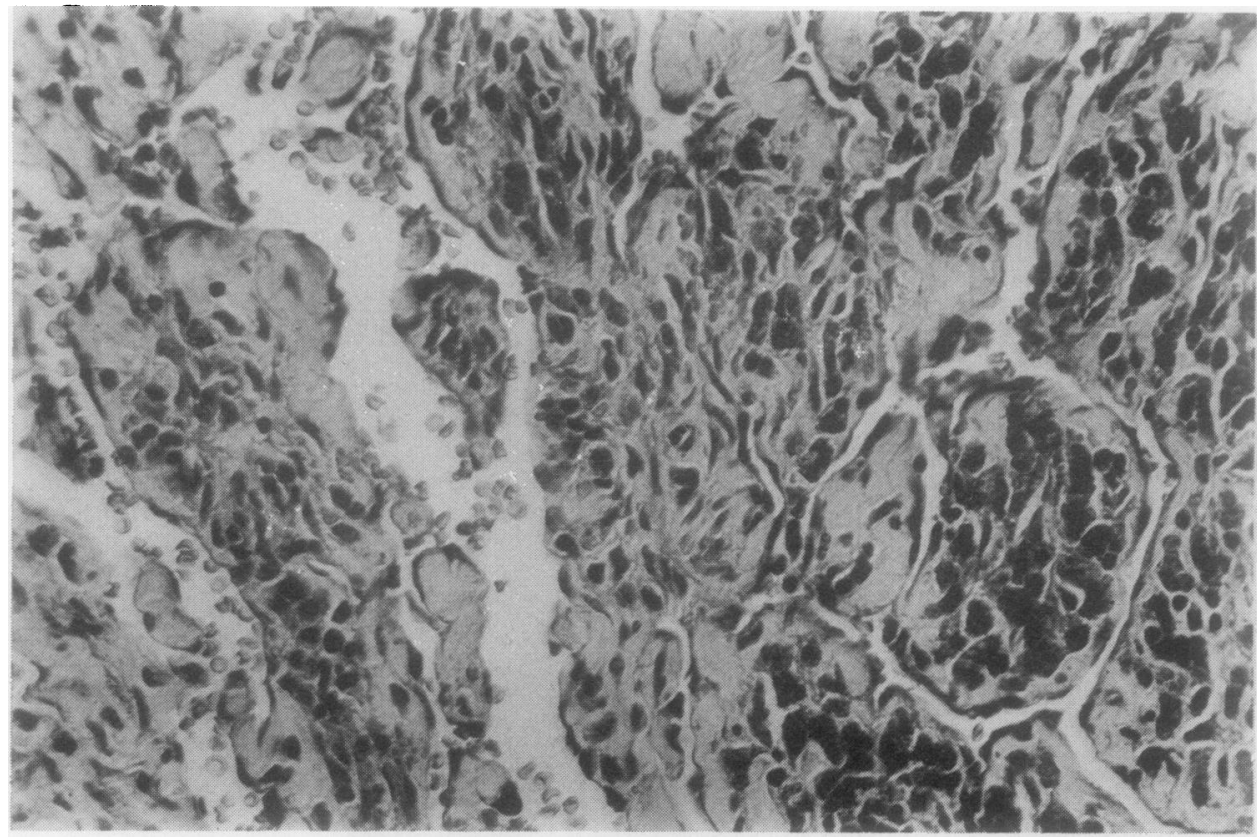

Fig 4 Case 5 (recurrence). Higher-power view of a similar area to that shown in figure 3. Much haemosiderin is present. $H$ and $E \times 210$. 
macrophage-type cells which form the main cellular component of the PVNS lesion.

Neither the site of these lesions nor the young age groups in which they occur is helpful in differentiating them from PVNS. Although the finger is one of the commonest sites for PVNS, the lesion there is almost invariably of the nodular type (Byers et al, 1968), while these vascular hamartomata are likely to be confused with the villous form.

While these points may be of help in differentiating between papillary organizing thrombus in a vascular hamartoma and PVNS, the single most important factor is an awareness of the necessity for making such a distinction.
The author is indebted to Dr Mary E. Catto, Reader in Orthopaedic Pathology at the University of Glasgow, for her help in the preparation of this paper.

\section{References}

Byers, P. D., Cotton, R. E., Deacon, O. W., Lowy, M., Newman, P. H., Sissons, H. A., and Thomson, A. D. (1968). The diagnosis and treatment of pigmented villonodular synovitis. J. Bone Jt Surg., 50B, 290-305.

Sevitt, S. (1973). The mechanisms of canalisation in deep vein thrombosis. J. Path., 110, 153-165.

Wright, C. J. E. (1949). Rapid recurrence of a giant-cell synovioma of tendon sheath. J. Path. Bact., 61, 271-274. 